\title{
Hobbes on the Order of Sciences A Partial Defense of the Mathematization Thesis
}

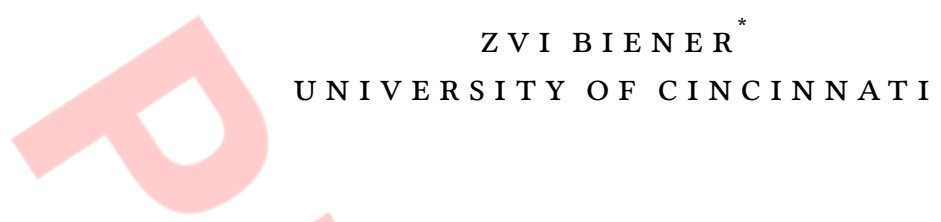

\begin{abstract}
Abtract. Accounts of Hobbes's 'system' of sciences oscillate between two extremes. On one extreme, the system is portrayed as wholly axiomatic-deductive, with statecraft being deduced in an unbroken chain from the principles of logic and first philosophy. On the other, it is portrayed as rife with conceptual cracks and fissures, with Hobbes's statements about its deductive structure amounting to mere windowdressing. This paper argues that a middle way is found by conceiving of Hobbes's Elements of Philosophy on the model of a mixed-mathematical science, not the model provided by Euclid's Elements of Geometry. I suggest that Hobbes is a test case for understanding early-modern system-construction more generally, as inspired by the structure of the applied mathematical sciences. This approach has the additional virtue of bolstering, in a novel way, the thesis that the transformation of philosophy in the long seventeenth century was heavily indebted to mathematics, a thesis that has increasingly come under attack in recent years.
\end{abstract}

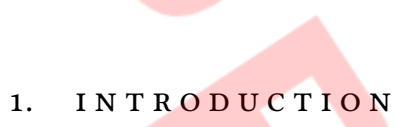

The idea that mathematics was central to the transformation of philosophy in the long seventeenth century is well known. It has roots in several twentieth-century polymathsAlexandre Koyré, E. A. Burtt, and E. J. Dijksterhuis-and has been with us long enough that it is considered a conservative historiographical device 1 But scholars have increasingly disputed its truth. They argue that much early-modern philosophical production was anti-mathematical both in theory and practice. Mordecai Feingold, for example, shows that those who accepted the primacy of mathematics in natural philosophy were "a divisive clique that had little in common with the interests and concerns of the generality of membership" of the Royal Society $\left.\right|^{2}$ Roger Ariew, for another example, shows that the

\footnotetext{
"I thank Peter Machamer and the participants of the 2010 National Endowment for the Humanities Summer Seminar on Galileo, Descartes, and Hobbes, lead by Dan Garber and Roger Ariew, for comments on the first version of this paper. For extensive comments on later drafts, I thank Marcus Adams, who has been independently working on understanding Hobbes's natural philosophy in terms of mixed-mathematics. I also thank two anonymous referees for their perceptive comments. Final work was generously supported by the Charles Phelps Taft Research Center Fellowship Program, at the University of Cincinnati.

1 Burtt, The Metaphysical Foundations of Modern Physical Science Koyré, Études Galiléennes Dijksterhius, The Mechanization of the World Picture Cohen, The Scientific Revolution: A Historiographical Inquiry Ch. 2. "Feingold, "Mathematicians and Naturalists" 78.
} 
varieties of Cartesianism demonstrate that the adoption of mathematical techniques was not central even to those who accepted a good deal of Cartesian metaphysics ${ }^{3}$ Finally, Daniel Garber shows that the concept of a "law of nature"-a decidedly mathematical one from a contemporary perspective-had a history that is largely distinct from the history of mathematization ${ }^{4}$ These are not claims about peripheral counter-currents in the scientific revolution, they are about its core. They thus leave us with a problem: if the use of mathematics was not essential to the transformation of philosophy in the seventeenth century, what becomes of the mathematization thesis?

In this essay I mount a programmatic, partial defense of the mathematization thesis. My defense consists of two intertwining claims: first, many discussions of the thesis wrongly characterize, if only by lack of attention, the extension of the term 'mathematics' in early modernity; second, this mischaracterization leads us to underappreciate one manner in which mathematics was was important for philosophy. I use Hobbes as a test case. My defense is partial because I only outline enough of the Hobbesian background to articulate the main claim; a full defense would require much more. Moreover, I do not intend to resuscitate the idea that mathematization was the engine of the scientific revolution. I only wish to show that mathematics played an underappreciated, but determinative role in the thought of one philosopher. While I believe that we can find similar instances in works of others, I cannot address them here $5^{5}$ To spell out what is underappreciated in the early-modern use of mathematics, I need to bring up another common element of early-modern philosophy.

It is well known that the project of constructing a 'system' of knowledge-a set of theses capable of integrating all that is and could possibly be known-was common to many early-modern philosophers. The most famous are perhaps Hobbes and Spinoza, although they were certainly not the only ones who tried to construct bodies of knowledge that consistently accounted for both experimental and abstract theses. That unity has been often understood in terms of mathematics. Mathematics, the idea goes, provided the organizing principle for philosophical systems, whether or not mathematics also provided the content of those systems. Thus, it was possible for Spinoza to champion the geometrical manner as an organizing principle for philosophy, and still circumscribe rather heavily the epistemic utility of mathematics ${ }^{6}$ In fact, the idea that mathematics provided a model for system construction is almost as prevalent as the mathematization

Ariew, Descartes and the First Cartesians Ch. 4.3.

Garber, "Laws of Nature and the Mathematics of Motion"

${ }^{5}$ See Biener, The Unity of Science in Early-Modernity: Subalternation, Metaphysics and the Geometrical Manner in Late Scholasticism, Galileo and Descartes

${ }^{\circ}$ The importance of the geometrical manner for Spinoza is a traditional, perhaps dated, position. Recent literature argues that Spinoza thought that very little about reality could be understood through mathematics. See Schliesser, "Spinoza and the Philosophy of Science: Mathematics, Motion and Being]'; Peterman, "Spinoza on Extension"

January 14, 2016 | 2 of 20 zvi.biener@uc.edu 
thesis itself. Importantly, however, this idea takes Euclidean geometry to provide the relevant structure for studying philosophical systems, even when the philosophical systems studied contained anti-mathematical theses and criticisms of Euclid himself $\left.\right|^{7}$ The following represent an orthodox position:

[I]t was Euclid and Archimedes who, fully in the tradition of Plato and Aristotle, established mathematics and the natural sciences as axiomatic-deductive theories: axiomatic in their fundamental principles, and deductive in their logical procedures. Their work has so far been the model for Thomas Hobbes (Politics), Baruch de Spinoza (Ethics), Leibniz (furisprudence), William Whiston (Cosmology) and many more, and has thus become the unique paradigm for strict science in the Western sense: as science 'more geometrico' 8

What few noticed, however, is that this view of system construction reinforces skepticism about the mathematization thesis! For if we take the Euclidean model to be the aim of, say, Hobbes and Spinoza, we must also announce them to be grand failures. Neither succeeded in creating systems that are actually axiomatic-deductive. Spinoza presented his system as axiomatic-deductive, but no student of Spinoza can feign that the claims of Book V of the Ethics are deducible in an unbroken chain from the principles of metaphysics.

Hobbes did not present his system in a geometrical fashion, but it is equally hard to find a single line of reasoning that begins with the principles of De Corpore and ends in statecraft. Nevertheless, I believe we can rescue him from failure, and we can do so by amending the Euclidean model of system construction. By revising the extension of the term 'mathematics,' we can see that what Hobbes, my example in this essay, tried to emulate was different than the strict Euclidean model. Rather, he tried to emulate a more flexible mixed-mathematical model, and this model allows us to turn some of his failures into successes. The two claims together establish that there is still room for the mathematization thesis-at least as far as system construction is concerned-if we properly revise what we understand by 'mathematization.' I begin by considering how mathematics was used by Hobbes, in general.

\footnotetext{
${ }^{7}$ I mentioned Spinoza above. The same is true for Hobbes, who repeatedly criticized Euclid in Six Lessons. Hobbes's criticism, however, was not leveled at the Euclidean idea of demonstration or the propositional structure of Euclidean geometry. Hobbes was mainly concerned with redefining basic geometrical concepts so that they reveal true causes. He also repeated praised Euclid, e.g., in the preface to De Corpore. For the causal definitions Hobbes sees as missing from Euclid, see Adams, "The Wax and the Mechanical Mind: Reexamining Hobbes's Objections to Descartes's Meditations

'Schönbeck, "Euclidean and Archimedean traditions in the Middle Ages and the Renaissance"' 184.
} 
Hobbes was taken with mathematics, particularly with geometry. Although the story of his Euclidean illumination is apocryphal and self-promulgated, his repeated statements regarding his genuine respect for the field and its importance for human knowledge are numerous and well known 9 But what did Hobbes take from Geometry? What was it about the field that appeared to him so useful? There are several available answers. The most cited holds that Hobbes took from geometry a certain conception of the resolutive and compositive methods, a way of moving from consequences to antecedents to consequences; or, given Hobbes's refusal to segregate, and perhaps confusion between, reasons and causes, a way of moving from effects to causes and back to effects ${ }^{10}$ A second story is that Hobbes took from geometry a respect for conceptual clarity, a respect for definitions free of vagueness and confusion, and for signs that denote only such definitions. This respect is usually discussed in the context of Hobbes' theory of definition, but given the primary role of definitions in Hobbes' system, it extends to his philosophy as a whole 11 A third story is that Hobbes took from geometry an insistence on demonstrative intersubjectivity, on styles of proof that could be understood by everyone ${ }^{12}$ A fourth story concerns certainty, and so on ${ }^{13}$ I don't wish to dispute any of these, each emphasizes the importance of mathematics in a different way.

But there is also another way Hobbes used geometry: as a model for system construction 14 This use is understudied, due to a kind of presentism. Much of the secondary literature on Hobbes and geometry takes for granted that the extension of "geometry" is known ${ }^{15}$ It assumes that Hobbes understood by "geometry" simply that body of knowl-

Aubrey, 'Brief lives,' chiefly of contemporaries, set down by John Aubrey, between the Years of 1669 \& 1696 1:332; Berhardt, "Témoinage direct de Hobbes sur son 'illumination Euclidienne'|"

${ }_{10}^{10}$ Sacksteder, "Hobbes: Geometrical Objects'; Sacksteder, "Hobbes: The Art of the Geometricians'; Talaska, "Analytic and Synthetic Method according to Hobbes"; Hattab, "Hobbes's and Zabarella's Methods: A Missing Link'; Adams, "The Wax and the Mechanical Mind: Reexamining Hobbes's Objections to Descartes's Meditations

14 Adams, "The Wax and the Mechanical Mind: Reexamining Hobbes's Objections to Descartes's Meditations'; Pettit, Made with Words: Hobbes on Language, Mind, and Politics Ch. 2.

${ }^{14}$ Grant, "Geometry and Politics: Mathematics in the Thought of Thomas Hobbes'; P. K. Machamer, "The Person-Centered Rhetoric of Seventeenth-Century Science"

${ }_{15}^{1}$ Popkin, The third force in seventeenth-century thought 9-49; Tuck, "Optics and sceptics: the philosophical foundations of Hobbes's political thought"

${ }^{14}$ See also Adams, "The Wax and the Mechanical Mind: Reexamining Hobbes's Objections to Descartes's Meditations." Adams, "Hobbes on Natural Philosophy as 'True Physics' and Mixed Mathematics"

${ }^{15}$ Historians of science have not make this error for several decades, but the presentism is still part of work on Hobbes's philosophy of language and politics, and thus often affects treatments of the unity of his system; see, e.g., Daston et al., Natural Law and Laws of Nature in Early Modern Europe: Furisprudence, Theology, Moral and Natural Philosophy 7 and Deigh, "Reasons and Ethics in Hobbes's Leviathan" Mostly, the problem is one of omission. By not specifying the extension of 'geometry' contemporary authors invite misinterpretation. This presentism persists despite the fact that questions about the Euclidean structure 
edge explored in Euclid's Elements, supplemented by the work of Apollonius, Pappus and a few others. Of course, that Hobbes saw Euclid, Apollonius, and Pappus as the pillars of geometry is not up for debate. Nevertheless, things are more complicated.

By the terms "mathematics" and "geometry," early moderns in the long seventeenth century referred to a wider set of disciplines than what we today understand by "mathematics" and "geometry." Galileo's initial university title, for example, was "mathematician," yet his published work was not a straightforward development of what we find in Euclid, Apollonius, or Pappus. No contemporary objected that he did not deserve his title for that reason. A broad understanding of the term was not unusual. Goclenius, for example, in the 1613 Lexicon, wrote under the entry Mathematicae that not only geometry and arithmetic, but also astronomy, optics, music and mechanics are accepted as "mathematics.:16 He then produced a table in which mathematics contains not only the four disciplines just mentioned, but also architecture, geography, and others (Figure 1).

[width=0.7]/Users/zvb1/Dropbox/Projects/Hobbes/goclenius.pdf

Descartes, reporting on his youth in the Regulae ad directionem Ingenii, wrote:

When [I had been lead] from the particular study of arithmetic and geometry to a general study of mathematics, I inquired first of all precisely what everyone means by this word, and why not only those two sciences of which we have already spoken, but also music, optics, mechanics, and several others are called parts of mathematics 17

Finally, Hobbes, in his commentary on White's De Mundo of 1642-43, wrote:

Some parts of philosophy, such as astronomy, mechanics, optics, music, are mathematical; others, still untouched, deal with quantity and number, not merely in theory but with reference to the movement of celestial bodies or that of heavy ones, or to the action of shining or sound-producing bodies; [these] must therefore be counted among the mathematical sciences ${ }^{18}$

When early-moderns referred to mathematics, they referred to both the pure and the so-called mixed-mathematical sciences. They referred both to the work of Euclid, Apollonius, and Pappus and to the work of Archimedes, Grosseteste, Benedetti, Brunelleschi,

of Hobbes's system have long been part of the literature on Hobbes; see e.g., Schuhmann, "Le Short Tract, premiere oeuvre philosophique de Hobbes" although the authorship of Short Tract, Schuhmann's subject, is disputed. Although I ultimately disagree with Schumann's conclusions about the origin of Hobbes's "structure," I agree that the source is not straightforwardly Euclidean. I thank Marcus Adams for drawing the Deighton piece to my attention.

${ }^{1}$ Goclenius, Lexicon philosophicum, quo tanquam clave philosophicae fores aperiuntur

$17 \overline{\mathrm{CSM}}$ I 19; $\mathrm{AT}$ X 377.

${ }^{18}$ Hobbes, Thomas White's De Mundo Examined 
Copernicus, Kepler, Galileo, and the large number of practitioners of ballistics, perspective, tuning, navigation, and architecture that sprang up in the renaissance 19

We can now return to the initial question, reframed: what did Hobbes take from geometry, if he also took geometry to be constituted by both pure geometry and the variety of mixed-geometrical disciplines? How adding mixed geometry to the extension of "geometry" changes the Hobbesian perspective on analysis and synthesis, or the clarity, intersubjectivity, and certainty of mathematics is beyond our scope. In those areas both pure geometry and mixed geometry can serve as exemplars, and so teasing out the separate influence of each type is no small feat ${ }^{20}$ However, there is one lesson that Hobbes could only have taken from mixed-geometry, one that is unavailable when geometry is considered in its pure form. It concerns the structure of deductive inference, and, given the importance of the deductive model for system-construction, the structure of his philosophical system. My claim is that Hobbes took something regarding philosophical system building from astronomy, optics, mechanics, and music. To see this, a brief overview of the debates regarding the structure of the Hobbesian system is in order.

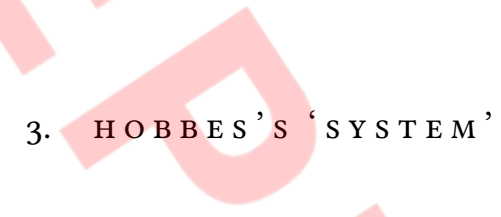

The debates regarding the structure of the Hobbesian system oscillate between two extremes mapped out decades ago. On the one hand, scholars endorse the demonstrative unity of Hobbes's system. Alan Ryan, for example, echoing earlier work by John Watkins, writes:

Hobbes believes as firmly as one could that behaviour, whether of animate of inanimate matter, was ultimately to be explained in terms of particular motion: the laws governing the motions of discrete material particules were the ultimate laws of nature, and in this sense psychology must be rooted in physiology and physiology in physics, while the social sciences, especially the terminology of statecraft, must be rooted in psychology 21

Such statements are easy to make, but explicitly tracing science to its roots is another matter. Ryan's focus on (some of) Hobbes's pronouncements does not easily match Hobbes's actual practice. One is hard-pressed to find the connection between, say, Hobbes's statecraft and physics, spelled out in his work. It is precisely such a mismatch that leads to the other extreme of Hobbesian scholarship. Tom Sorell holds that:

\footnotetext{
${ }^{19}$ See P. Machamer, "Galileo and the Causes'; Dear, Mersenne and the Learning of the Schools

${ }^{2}$ Adams, "The Wax and the Mechanical Mind: Reexamining Hobbes's Objections to Descartes's Meditations' admirably teases out the separate influences insofar as certainty and clarity are concerned.

${ }^{2}$ Ryan, The Philosophy of the Social Sciences 102-103. Watkins, Hobbes's system of ideas: a study in the political significance of philosophical theories
} 
Hobbes was a firm believer in the unity of science, but he did not think that deductive links kept the body of science whole.... That is, he did not suppose that the sciences could all be ranged in a series that the mind could take in as it takes in a geometrical demonstration...22

The problem is there is evidence for both interpretive extremes in Hobbes, and this is precisely why this debate has gone unsettled. Noel Malcolm provides a clear description of the difficulty:

If we attempted to follow Hobbes' "method" through, ascending from one level of knowledge to the next, we would find that each new level required the introduction of concepts which were simply not contained in the subject-matter of the previous level. [For example,][p] hysics will give us the concept of "motion toward" and "motion away from"; but only psychology will provide the concept of "desire" and "fear."23]

Nevertheless, there have also been several attempts to bridge extremes. An appealing, but relatively ignored, proposal is due to Peter Machamer and Spyros Sakellariadis (henceforth: $M \& S)$.

In an essay on "The Unity of Hobbes Philosophy," M\&S respond to the above interpretive dilemma by invoking Hobbes's nominalism ${ }^{24}$ Their argument is based on the fact that for Hobbes the fundamental linguistic unit is the name and that "a universal [name] gains its meaning from the various particular objects it supports[.] 25 Hobbes may sometimes speak as if a single name can be applied to various objects because of "their similitude in some quality or other accident," but, as M\&S stress, this similitude is a consequence of defining the name under whose extension these objects fall. Defining a name specifies how objects in its extension are to be conceived, and so understanding of their similitude "in some quality or other accident" depends on the definition of the quality or accident in question. It follows from this view that a name can apply across domains which may appear essentially different to a non-nominalist, and by so doing unify those domains ${ }^{26}$ Moreover, no domain is privileged. The name does not apply strictly in one domain but only loosely or metaphorically in another. Rather, the name captures all objects in its extension equally. M\&S write:

22 Sorell, "Descartes, Hobbes and the Body of Natural Science" 520.

$2:$ Malcolm, "Hobbes's Science of Politics and his Theory of Politics." 147. Malcolm's view is consonant with the mixed-mathematical view. In fact, I take the mixed-mathematical view defended in this paper to provide a concrete model by which to articulate the introduction of new concepts at different levels of Hobbes's system. I thank an anonymous referee for urging me to clarify this point.

${ }^{2}$ P. Machamer and Sakellariadis, "The Unity of Hobbes's Philosophy",

25 P. Machamer and Sakellariadis, "The Unity of Hobbes's Philosophy" 31.

${ }^{26}$ See also Leviathan §4.6. Pettit, Made with Words: Hobbes on Language, Mind, and Politics Ch. 2 explores problems with this notion of similitude.

January 14, 2016 | 7 of 20 zvi.biener@uc.edu 
The effects of this nominalism are readily seen in the case of the concept of motion. "Motion" is a universal term and therefore as our knowledge of it "we have in the first place (its) definition' (De Corpore, 70). Thus, through its application in different realms we come to know about motion. For example, in the case of natural philosophy, motion is the endeavor or motion of corporeal objects, defined as the continual relinquishing and acquiring of places of the objects. In moral philosophy, the motions are the endeavors or motions of the mind, namely 'appetite. aversion, love, benevolence, hope, fear, anger, emulation, envy, etc.' (De Corpore, 71). The fundamental law of motion, for example, refers both to the fact that corporeal objects continue to endeavor to change their places unless hindered, and to the fact that human beings continue to have appetites and aversions (both endeavors), and, unless hindered, will change their place in order to accomplish the goals of those motions ${ }^{27}$

The view is attractive, but not without it's problems. First, M\&S seem to assert both that the meaning of Hobbes's key terms is univocal across domains and that it (partially) varies. For example, they contend that "universal terms, like 'body', 'law', 'motion', etc.,... are used with the same meaning throughout Hobbes's system.'28 But they also suggest that " $[\mathrm{t}]$ he meaning of the term 'body' employed in any particular realm (e.g., politics) is determined not only by that realm itself, but also by the other realms in which it applies (e.g., natural philosophy): ${ }^{29}$ The two are at odds. The second suggestion implies that the term "body" is not used with the same meaning in the physical, moral, and political levels. Rather, it has a wide, hybrid meaning that is narrowed when any domain is specified. Similarly, according to the first suggestion, if a term had the same meaning everywhere, there would be no reason to consult other domains when trying to understand its meaning in a given domain. Conceiving of it's extension in one domain would be sufficient. Its meaning in one realm would not be partially determined "by the other realms in which it applies."

Second, and more importantly, M\&S fail to account for the order of Hobbes's system. They cannot explain, for example, why one would need to know about the motion of inanimate matter before reasoning about sense. On one hand, if the meanings of terms were the same across domains, nothing about the application of a term in one domain would have to be understood for its application in another. One could study, for example, how animal motion has features of "motion" without knowing anything about the motion of inanimate bodies. Knowing about the motion of inanimate bodies would add nothing at all to one's knowledge of "motion" in animals ${ }^{30}$ And if one can reason about domains

\footnotetext{
${ }^{27}$ P. Machamer and Sakellariadis, "The Unity of Hobbes's Philosophy" 31-32. Hobbes sometimes presents "scientia" as knowledge of causes and sometimes as knowledge of meanings. The latter allows knowledge of motion to be part of scientia even when a causal definition of motion is unavailable. M\&S skirt this issue here, and so will I. For an account that stresses that causal reading, see Adams, "The Wax and the Mechanical Mind: Reexamining Hobbes's Objections to Descartes's Meditations",

${ }^{2}$ P. Machamer and Sakellariadis, "The Unity of Hobbes's Philosophy" 20, original emphasis; 32.

${ }^{2}$ P. Machamer and Sakellariadis, "The Unity of Hobbes's Philosophy" 31.

${ }^{30}$ Hobbes does allow some domains (like politics) to have this kind of independence, but certainly not all.
} 
independently, knowledge of those domains need not be ordered in any way. On the other hand, if the meanings of terms were hybrid-so that "the meaning of [a] term... is determined... by the other realms in which it applies," one would need to study all realms before fully understanding what a term means in a particular realm. Either way, the ordering gets lost in M\&S's account.

Yet there is no context I am aware of in which Hobbes discusses the unity of his system without explicitly highlighting its order. For example, in De Corpore, he writes:

[I]n the first place those things be demonstrated, which immediately succeed to universal definitions (in which is contained that part of philosophy which is called philosophia prima). Next, those things which may be demonstrated by simple motion (in which geometry consists). After geometry, such things as may be taught, or shewed by manifest action, that is, by thrusting from, or pulling towards. And after these, the motion or mutation of the invisible parts of things, and the doctrine of sense and imaginations, and of the internal passions, especially those of men, in which are comprehended the grounds of civil duties, or civil philosophy; which takes up the last place. And that this method ought to be kept in all sorts of philosophy, is evident from hence, that such things as I have said are to be taught last, cannot be demonstrated, till such as are propounded to be first treated of, be fully understood ${ }^{31}$

As far I know, Hobbes is never explicitly concerned with "unity" (or any relevant cognates). Rather, he is concerned with deductive order. M\&S’s account requires modest modification. This is where the mixed-mathematical model of system construction becomes useful.

\section{MIXED MATHEMATICS}

Although the term "mixed-mathematics" only became common currency in the renaissance, philosophical reflection on the nature of optics, astronomy, and harmonics traces back to Aristotle's Physics and, more significantly, Posterior Analytics. In the latter text, Aristotle holds that scientific demonstrations can furnish true claims regarding a science's subject matter by showing what properties belong to it by virtue of the kind of thing it is, its genus, not by virtue of any properties that are accidentally true of it. This entails that, for the most part, the premises and conclusions of scientific demonstrations are homogeneous-they concern the same genus. Thus, metaphysical truths only follow from metaphysical premises, physical truths from physical premises, mathematical truths from mathematical premises, etc.

See Sorell, "The Sciences in Hobbes's Politics' and Malcolm, "Hobbes's Science of Politics and his Theory of Politics"

\footnotetext{
${ }^{31} \mathrm{De}$ Corpore $§ 6.17$. The above is partially quote by $\mathrm{M} \& \mathrm{~S}$, but they omit the important first sentence.
} 
But Aristotle also admitted of exceptions. In certain sciences, truths regarding one genus could be used in reasoning about another genus. For example, optics uses geometrical truths to reason about visual rays and harmonics uses arithmetical truths to reason about sounds. In each case, the demonstrations are said to cross-genera: they borrow principles that, strictly speaking, apply only to one kind (namely, continuous or discrete magnitude) and apply it to another kind (namely, visual ray or sound). Because optics and harmonics borrowed principles from geometry and arithmetic, optics and harmonics were said to "stand beneath the other," pure mathematical sciences ${ }^{32}$

The latinization of Aristotle's "stand beneath the other" resulted in a technical term that persevered to the early-modern period-"subalternation"-and a body of work built on Aristotle's relatively few comments on the matter. Robert Grosseteste, in particular, theorized the unique status of the mixed-mathematical or subalternate sciences in language that reverberated in many later commentaries, starting with Aquinas and reaching to Suarez and the Coimbrans. According to Grosseteste:

A science, is subalternated to another, whose subject adds a condition onto the subject of the subalternating science... which condition does not totally derive from the nature of the subject of the subalternating [science], but is assumed from without 33

Consider the science of optics. In geometrical optics, theorems of geometry are used to deduce a broad range of claims about light rays and vision. Why geometry? Because light rays and vision seem to travel in straight lines. If the entities and processes of optics were not characterizable (at least partially) by geometrical concepts, geometry would have no foothold. However, the entities and processes of optics cannot be wholly characterized by geometrical concepts. If they were, there would be no distinction between the geometry and optics. Put differently, a study of geometrical optics must use principles that are not essentially geometrical, if geometry and optics are to be different sciences. Here is a common example, due to Richard McKirahan ${ }^{34}$ In deducing claims about the apparent size of objects, proofs in geometrical optics use the principle that the larger the angle an object subtends in the visual field, the larger it appears. Given this principle, geometrical optics answers questions like: Given two unequal objects, in what range of positions will the two appear equal? Or, how much smaller will an object appear if viewed obliquely? Equally, geometrical optics can explain why objects can appear equal when they are

\footnotetext{
${ }^{32}$ See Posterior Analytics I.13. For an introduction to the topic see McKirahan, Principles and Proofs: Aristotle's Theory of Demonstrative Science Randall, "The Development of Scientific Method in the School of Padua The Development of Scientific Method in the School of Padua" and South, "Zabarella, Prime Matter, and the Theory of Regressus"

${ }^{5}$ Grosseteste, Commentary on Posterior Analytics, I. 18, 41-45. See Laird, The Scientiae Mediae in Medieval Commentaries on Aristotle's Posterior Analytics Ch. 1.

McKirahan, "Aristotle's Subordinate Sciences" The example is from Euclid's Optics.
} 
not, or appear unequal when they are, an explanation that relies on the geometrical configurations of the objects under study. The principle in question, however, is not deducible from the axioms of geometry. Although it uses geometrical concepts (e.g., angle), it is not a geometrical principle. Rather, it is an "added condition" that concerns the operation of vision in the domain of optics. Combining this principle with the principles of geometry allows us to answer optical questions, but neither the principle itself nor the principles of pure geometry are separately sufficient for the task.

Four main points are relevant here: First, one cannot have a lower, subalternated science, without some principles peculiar to the its domain. Grosseteste and other Aristotelians offered theories of induction to explain how the principles of subalternated sciences are discovered, but the main point is that they do not come from higher sciences 35 They are assumed, as Grosseteste put it, from without. Many commentators put the same point in terms of qualities and properties: the lower science must add some quality or property to the higher science, as optics adds "visual" to the line studied by geometry. Principles that characterize the added property-as the above principle characterizes the property of 'being seen'-can then be used in demonstrations alongside the principles of the 'higher' science.

Second, principles from pure geometry are assumed within optics, they are not justified anew. Many commentators held that an optician is insulated from purely geometrical worries, as a pure geometer is insulated from geometry's optical application ${ }^{36}$ It is the job of the higher science to provide justified principles, but not to apply them; and it is the job of the lower science to apply higher-order principles, but not to justify them. Consequently, no result in optics can cast doubt on results from pure geometry and proofs in pure geometry are, strictly speaking, beyond the purview of the optician, when she is confined to her "proper business. ${ }^{37}$ We will return to this disciplinary insulation in the conclusion.

Third, in a demonstration that combines a higher and lower science to prove some conclusion in the lower science, the higher is said to provide a deeper explanation of the conclusion. What 'deeper' amounts to can vary from commentator to commentator, but, broadly speaking, must answer to one of the Aristotelian causes. Often, the higher sciences were said to provide demonstrations of "the reasoned fact," "the why," or simply

\footnotetext{
${ }^{35}$ I bracket a further discussion of the origins of the 'extra conditions.' For many working in a broadly Aristotelian mold, the extra conditions were a result of induction, but a review is beyond my scope. The same problem arises for Hobbes, of course, which I also bracket. For the ways in which induction can yield appropriately general, and true, definitions and principles, see Bayer, "Coming to Know Principles in "Posterior Analytics" II 19' and Charles, Aristotle on Meaning and Essence

${ }^{30}$ This disciplinary insulation was crucial to the reception of the mixed-mathematical sciences in midseventeenth-century Paris. See, for example, Dear, Mersenne and the Learning of the Schools and Garber, "Defending Aristotle / Defending Society in Early 17th Century Paris"

3: Simplicius, On Aristotle's Physics 2294.
} 
"the cause," while the lower sciences provided demonstrations of "the [unexplained] fact" or "the what." This broadly causal requirement could appeal to formal, efficient, or even final causes 38

Fourth, and going back to our principal question, because optics, due to its subalternation by geometry, is a kind of geometry, an optical demonstration doesn't just use the basic framework of a geometrical demonstration, it is a geometrical demonstration. And as a geometrical demonstration, it comes with all the perks associated with pure geometry: certainty, clarity, intersubjectivity, possible use as part of an analysis/synthesis, etc. 39

For Aristotle himself, only the mixed-mathematical sciences (and perhaps medicine) were allowed to cross-genera. However, at the hands of the late scholastics, the concept of subalternation came to have a broad application. By the 17th century, although the exemplars of subalternation remained the mixed-mathematical sciences, subalternation was used as a relation that could obtain between any two sciences when one borrows principles from another and applies them in its own, peculiar domain. Subalternation even came to apply to the relationship between metaphysics and the remainder of the

\footnotetext{
${ }^{38}$ The absence of material causes from the list is due to the fact that the lower science was also said to provide the matter of the demonstration, while the higher science provided the form, or that the lower science considered the objects of the higher science, but enmattered. Either way, appeal to a material cause in the higher science would run afoul of several key characterizations of the subalternating relation. For a single example, take Philoponus's characterizations of the relation of arithmetic and harmonics: "[G]eometry and arithmetic simply look at double and one-and-a-half and such [relations] separably, while the harmonicist, since he studies such formulas (logos) as actually being properties [of something], cannot even think of them without matter" (Philoponus, On Aristotle's Physics 2 227,1 9-13, emphasis added). The various terms intended to capture the relation of causes in subalternating and subalternate sciences take their cue from Posterior Analytics I 9, 76a10-16 and are re-workings of Aristotle's 'the fact' ( ) and 'the reason' ( ).

${ }^{39}$ The inference from the 'perks' of a subalternating science to the 'perks' of a subalternated science is by no means facile. Although I have lumped certainty, clarity, intersubjectivity and use in analysis/synthesis together, authors may explain the presence of one through the presence of others, and may even explain the presence of all through the presence of more fundamental features like proper appeal to causes. For example, Hattab, Descartes on Forms and Mechanisms 110-119, shows that Ioannis de Guevara, "a priest, friend of Galileo, and Aristotelian," defended the certainty of mechanics (which he conceived to be subalternate to geometry) by first pressing mechanical demonstration into syllogistic form, and then using the machinery of Aristotle's Posterior Analytics to argue that mechanical demonstrations make proper use of middle terms and are thus properly causal. Since they are causal, they can be used to infer causes from effects (demonstratio quia, analysis) and effects from causes (demonstratio propter quid, synthesis), and thus form an analytic-synthetic chain (the regressus). For Guevara, it is ultimately the regressus that guarantees the certainty of mechanical knowledge. I take Hattab's treatment of Guevara to support the current discussion, by showing how subalternated sciences were thought to inherit not only principles, but the epistemic characteristics of their subalternating sciences. I thank an anonymous referee for pointing this out. The above inference also relies on the idea that pure geometry itself rises to the level of scientia, a notion that was not at all above dispute. In fact, battles regarding the scientific nature of the subalternated science were often part of battles concerning the scientific nature of pure mathematics; on the Quaestio de Certitudine Mathematicarum (Disciplinarum), see Mancuso, Philosophy of Mathematics and Mathematical Practice in the Seventeenth Century For Hobbes's relationship to the regressus and his understanding of the benefits of a "mathematical" method see also Hattab, "Hobbes's and Zabarella's Methods: A Missing Link",
} 
sciences. Eustachius a Sancto Paolo, just to take a non-innovative, expository writer, noted:

Amongst Mathematics there are those which are called impure, or which consider quantity with some type of quality; indeed, Music, and Optics are subalternated by pure Mathematics, by Arithmetic or Geometry. And, finally, all sciences are subalternated by Metaphysics ${ }^{40}$

Although opinions differed regarding the extent of the subalternation relation (Francisco Suarez, for example, held that metaphysics does not subalternate all other sciences), it is clear that subalternation was part of the lingua franca of late scholasticism. It provided a way to think about inferences that crossed genera, and thus a way to think about broad disciplinary relations.

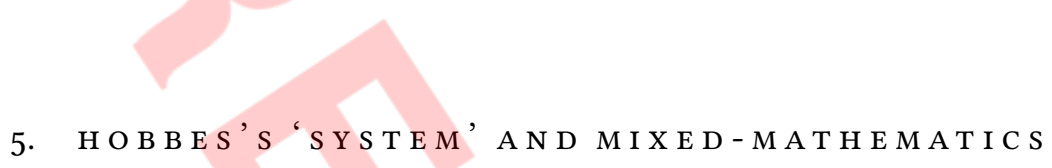

I'd like to suggest that one of the things Hobbes took from geometry and from his clear knowledge of scholasticism was this distinctly non-reductive, although nevertheless deductive, conception of inference, and with it a non-reductive, but unified, conception of knowledge ${ }^{41}$ The approach has the power to span the two interpretive poles mentioned earlier. On the one hand, we should not expect all of Hobbes's sciences to boil down to a few first principles. Taking mixed-geometry as a model does not entail, unlike taking pure-geometry as a model, that all conclusions must boil down to a finite set of axioms about a single, albeit highly abstract, domain. On the other hand, the various fissures between physics and physiology, or physiology and psychology, do not invalidate Hobbes's project as broadly geometrical. Such fissures were part and parcel of mixed-geometry and were caused by the addition of conditions at each transition from a subalternating to a subalternated science. In the quote below, Hobbes considers only "true physics," but his understanding of mixed-mathematics is such that any truly mixed science cannot be reduced to the abstract principles of the pure one. Rather, it takes those pure principles and adds ones peculiar to its more specialized domain. Hobbes also expands, as many scholastics and novatores before him, the number of the mixed sciences from their paradigmatic instances to include also physics, as a whole:

[S]ince one cannot proceed to the consequences or motions without a knowledge of quantity, which is geometry; ... Therefore physics (I mean true physics), that

\footnotetext{
${ }^{44}$ Eustachius a Sancto Paulo, Summa philosophiae quadripartita, de rebus Dialecticis, Ethicis, Physicis, \& Metaphysicis. I 242.

'See Leijenhorst, The Mechanisation of Aristotelianism: The Late Aristotelian Setting of Thomas Hobbes Natural Philosophy for Hobbes's engagement with late Aristotelianism.
} 
depends on geometry, is usually numbered among the mixed mathematics [mathematicas mixtas]... [T] hose mathematics are pure which (like geometry and arithmetic) revolve around quantities in the abstract ... those mathematics are mixed which in their reasoning also consider any quality of the subject, as is the case with astronomy, music, physics, and the parts of physics that can vary on account of the variety of species and the parts of the universe ${ }^{42}$

The idea that specific domains are constructed by "adding conditions" to higher, more generic domains can account for the ordering of Hobbes's system, can retain its unity, and can explain his abiding concern with the example of mixed mathematics. Another famous Hobbesian take on his Elements makes the point plain:

Having completed this section, On Man, I have finally fulfilled my promise. For you now possess the prime Elements of my philosophy in all its divisions and subdivisions. Moreover, it happens that the two parts whereof this section consists are very dissimilar... They are therefore somewhat abruptly conjoined; but this was necessary, granted the method of my work as a whole.

For man is not just a natural body, but also a part of the state, or (as I put it) of the body politic; for that reason he had to be considered as both man and citizen, that is, the first principles of physics had to be conjoined with those of politics [ultima physicae cum principiis politicae conjungenda erant $]. .{ }^{43}$

Hobbes's stated procedure is to take definitions in "higher" domains and add principles specific to lower domains. We also see this in Hobbes's characterization of the finer transition from Part II of De Corpore ("First Grounds of Philosophy", which include general concepts like velocity and cause) to Part III ("Proportions of Motion and Magnitude", which include uniform and accelerated motion) ${ }^{44}$ In brief: The first two sections of Part III are entitled: "1. Repetition of some principles of the doctrine of motion set down above" and "2. Other principles added to these: ${ }^{45}$ The first section repeats the causal and kinematic principles of motion in articulated in Part II, Chapter 8, and the second adds a new concept: endeavor (conatus). Conatus is defined as "motion made in less space and time than can be given", and it is the addition of conatus, a more highly specified type of motion, to the general principles of geometry that yields the variety of specific motions studies in Part III. For example, "uniform motion" is defined as an equality of impetus-a quantity of conatus-at every point of an object's trajectory ${ }^{46}$ Conatus itself is further specified in the transition to Part IV of De Corpore ("Physics"). As the conatus

\footnotetext{
${ }^{42}$ De Homine, Ch. X; OL II 93-94; Hobbes, Man and Citizen (De Homine and De Cive) 42, slightly modified, emphasis added.

${ }^{43}$ De Homine, preface; OL II v; Hobbes, Man and Citizen (De Homine and De Cive) 35, emphasis added.

${ }^{44}$ See Jesseph, "Hobbesian Mechanics' for how motion can be part of Hobbes's First Philosophy.

${ }^{45}$ De Corpore, Ch. 15. OL I 175.

${ }^{46}$ De Corpore, 16.1 ; OL I 184. Hobbes also adds that conatus must be towards something in De Corpore $15.5, \mathrm{OL}$ I 182.
} 
of an inanimate body is its minutest directional motion, the conatus of an animate body is an appetite when it is in the direction of an object that promotes the life-sustaining vital motion of the blood, and aversion when it is away from an object that inhibits vital motion. Appetite and aversion are still conati, but their targets and effects are more specific than conati in general. In Leviathan, appetites and aversions form the basis of Hobbes's psychology, thus also enabling the transition to statecraft, which is yet further down the subalternation chain 47

This approach has the promise of holding on to what is insightful in M\&S's approach, and addressing the problem of order. As M\&S emphasize, Hobbes's terms do have the same core meaning in every domain, and so principles concerning, say, conatus, apply in exactly the same way to natural philosophy and politics, or inanimate matter and living things. However, each domain adds additional conditions that are peculiar to that domain: the endeavor of an animate body is not identical to the endeavor of an inanimate one, although each is an endeavor. The endeavor of an animate body is directed towards promotion of vital motion, motion which does not exist in the inanimate world. Yet both sustain the body undergoing them, as they are able. The problem of order is solved because the earlier, higher domains provide a more general account of the concept in question, which the lower sciences further specify. And so, the adding of conditions provides an appropriate criterion for ordering. This structure answers to the other points made about mixed-mathematics in $\S 4$. A higher science provides the principle, say, that conatus is minute directional motion, which lower sciences take for granted. A discussion of appetite in the context of psychology no longer needs to include general deliberation about the nature of motion, since the properties which belong to the genus have already been determined. This provides the disciplinary insulation characteristic of mixed mathematics. Given Hobbes's emphasis on causal definitions, the higher sciences also provides the reason why certain claims are true in the lower sciences. They specify causes.

\section{C O N C L U S I O N}

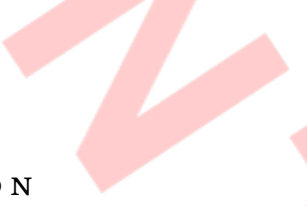

Before closing, I need to address a historical problem. If subalternation was part of the lingua franca of late scholasticism, why should we think Hobbes fixed on it as an organizing disciplinary principle by thinking about mixed-mathematics, and not by reading one of the many available scholastic treatments of the unity and structure of the

\footnotetext{
${ }^{47}$ Strictly speaking, subalternation is a binary, asymmetrical, and transitive relation, so that if science $\mathrm{C}$ is subalternated to B and B is subalternated to A, C is subalternated to science A. This means that sciences 'lower' in Hobbes's Elements are subalternated to all the sciences above them, up to first philosophy.
} 
sciences? My answer has two components. First, the question is somewhat misleading. Even within scholastic treatises and textbooks, the exemplars for subalternation were the mixed-mathematical sciences. I know of no discussion of subalternation that does not at some point mention the mixed-mathematical sciences as clear instances of the concept under discussion. With regards to disciplinary classification, (and unlike the case of substantial forms, for example) being impressed with mixed-mathematics did not stand opposed to taking scholastic doctrines to heart. Hobbes could have very well learned about the disciplinary and demonstrative status of mixed-mathematics from sources that did not set out to champion the new sciences.

There is also another answer. Hobbes began thinking of a system of philosophy not during or shortly after his studies, nor while in Bacon's employ, nor while translating Thucydides, but while in and out of Paris, precisely when he was immersed in the culture of mixed mathematics that permeated Mersenne's circle. For Mersenne and his circle, however, championing mixed-mathematics was politically plausible only because of the science's curious disciplinary status: by virtue of their rank in the disciplinary hierarchy, the new mixed sciences did not challenge metaphysical and theological authority ${ }^{48} \mathrm{~A}$ subalternating science, recall, was thought to be insulated from the sciences it subalternated. And so, if optical demonstrations could not cast doubt on geometrical proofs, they could certainly not cast doubt on the higher truths of theology and metaphysics. It was this feature of the mixed-mathematical sciences that rendered them safe: by practicing mixed-mathematics in the 1630s, Mersenne and friends were not only not challenging metaphysical and theological doctrine, orthodoxy suggested that they could not possibly do so! The Parisian Hobbes would have thus been uniquely positioned to think about the way in which demonstrations and disciplinary boundaries come together in the variety of geometrical sciences. Emulating geometry went hand in hand with avoiding "offensive novelty", as the epistle dedicatory to De Corpore claims to do.

I close by returning to the mathematization of early-modern philosophy. A good deal of literature is guided by a dual vision of early-modern mathematization efforts. On the one side stand Galileo, Huygens, and Newton; mixed-mathematicians who sought piecemeal solutions to particular problems and who happily dispensed with essences and ultimate causes. On the other side stand Descartes, Hobbes, and Spinoza; philosophers who sought to build complete, architectonic systems that grounded all that there is in its metaphysical roots. I think focusing on the demonstrative and disciplinary status of mixed-mathematics suggests that, at least in Hobbes's case, the two were not as opposed as they now seem. In fact, the very structure of some architectonic systems might have been suggested by the mixed-mathematical approach. To put it tendentiously, some

${ }^{4}$ Garber, "Defending Aristotle / Defending Society in Early 17th Century Paris'; ; Garber, "On the Frontlines of the Scientific Revolution: How Mersenne Learned to Love Galileo" 
philosophers might have learned to philosophize from mixed-mathematics.

B I B L I O G A P H Y A D A B B R E VIATION S

Adams, Marcus P. "Hobbes on Natural Philosophy as 'True Physics' and Mixed Mathematics." Studies in History and Philosophy of Science 56 (2016): 43-51.

--_. "The Wax and the Mechanical Mind: Reexamining Hobbes's Objections to Descartes's Meditations." British fournal for the History of Philosoph 22 (2014): 403-424. D O I: 10.1080/09608788.2014.893226

Ariew, Roger. Descartes and the First Cartesians. Oxford, United Kingdom: Oxford University Press, 2014.

Aubrey, John. 'Brief lives,' chiefly of contemporaries, set down by fohn Aubrey, between the Years of 1669 \& 1696. Edited by Andrew Clark. Oxford: Oxford University Press, 1898.

Bayer, Greg. "Coming to Know Principles in "Posterior Analytics" II 19." Apeiron 30 (1997): 109-142.

Berhardt, Jean. "Témoinage direct de Hobbes sur son 'illumination Euclidienne'." Revue philosophique 2 (1986): 281-282.

Biener, Zvi. The Unity of Science in Early-Modernity: Subalternation, Metaphysics and the Geometrical Manner in Late Scholasticism, Galileo and Descartes. University of Pittsburgh, 2008.

Burtt, Edwin A. The Metaphysical Foundations of Modern Physical Science. Garden City, N. Y.: Doubleday, 1954 [1932].

Charles, David. Aristotle on Meaning and Essence. Oxford University Press, USA, 2003.

Cohen, H. Floris. The Scientific Revolution: A Historiographical Inquiry. Chicago: University of Chicago Press, 1994.

Daston, Lorraine and Michael Stolleis. Natural Law and Laws of Nature in Early Modern Europe: Furisprudence, Theology, Moral and Natural Philosophy. Farnham, England: Ashgate Pub. Company, 2008.

Dear, Peter. Mersenne and the Learning of the Schools. Ithaca: Cornell University Press, 1988.

Deigh, John. "Reasons and Ethics in Hobbes's Leviathan." Journal of the History of Philosophy 34 (1996): 33-60. D o I: 10.1353/hph.1996.0001

Descartes, René. Oevres de Descartes. Edited by Charles Adam and Paul Tannery. Nouvelle présentation. Paris: J. Vrin, 1964.

---. The Philosophical Writings of Descartes. Volume I. Trans. John Cottingham, Robert Stoothoff, and Dugald Murdoch. 3 Vols. Cambridge; New York: Cambridge University Press, 1984. [CSM]

Dijksterhius, E. J. The Mechanization of the World Picture. Trans. C. Dikshoorn. Paperback (1986). Princeton University Press, 1961.

Eustachius a Sancto Paulo. Summa philosophiae quadripartita, de rebus Dialecticis, Ethicis, Physicis, \& Metaphysicis. Paris, 1609.

January $14,2016 \mid 17$ of 20 zvi.biener@uc.edu 
Feingold, Mordechai. "Mathematicians and Naturalists." In Isaac Newton's Natural Philosophy, edited by Jed Z. Buchwald and I. Bernard Cohen, 77-102. Cambridge, Mass.: MIT Press, 2001.

Garber, Daniel. "Defending Aristotle / Defending Society in Early 17th Century Paris." In Ideals and Cultures of Knowledge in Early Modem Europe (Wissensideale und Wissenskulturen in der fruhen Neuzeit), edited by Wolfgang Detel and Claus Zittel, 135-160. Berlin: Akademie Verlag, 2002.

-- - "Laws of Nature and the Mathematics of Motion." In The Language of Nature: Reassessing the Mathematization of Natural Philosophy, edited by Geoffery Gorham et al. University of Minnesota Press, forthcoming.

---. "On the Frontlines of the Scientific Revolution: How Mersenne Learned to Love Galileo." Perspectives on Science 12 (2004): 135-163.

Goclenius, Rudolph. Lexicon philosophicum, quo tanquam clave philosophicae fores aperiuntur. Rodolphus Goclenius. Reprint (1st work). Originally published: Francofurti : M. Becker, 1613. Added title page, engr. of original edition. Hildesheim,: G. Olms, 1964 [1613].

Grant, Hardy. "Geometry and Politics: Mathematics in the Thought of Thomas Hobbes." Mathematics Magazine 63 (1990): 147-154.

Hattab, Helen. Descartes on Forms and Mechanisms. New York: Cambridge University Press, 2009.

- - - "Hobbes's and Zabarella's Methods: A Missing Link." fournal of the History of Philosophy 52 (2014): 461-485. D O I: 10.1353/hph.2014.0057

Hobbes, Thomas. Man and Citizen (De Homine and De Cive). Edited by Bernard Gert. Trans. Charles T. Wood, T. S. K. Scott-Craig, and Bernard Gert. Hackett, 1991.

---. Thomae Hobbes Malmesburiensis opera philosophica quae latine scripsit omina. Edited by W. Molesworth. 5 Volumes. London: Scientia, 1845. [OL]

--- Thomas White's De Mundo Examined. The Latin translated by Harold Whitmore Jones. London: Bradford University Press in association with Crosby Lockwood Staples, 1976.

Jesseph, Douglas. “Hobbesian Mechanics.” In Oxford Studies in Early Modern Philosophy, Volume IV, edited by Daniel Garber and Steven M. Nadler, 119-152. Oxford: Clarendon Press, 2008.

Koyré, Alexandre. Études Galiléennes. Paris: Hermann, 1939.

Laird, W. Roy. The Scientiae Mediae in Medieval Commentaries on Aristotle's Posterior Analytics. PhD Thesis: University of Toronto, 1983.

Leijenhorst, Cees. The Mechanisation of Aristotelianism: The Late Aristotelian Setting of Thomas Hobbes' Natural Philosophy. Leiden, Boston, Köln: Brill, 2002.

Machamer, Peter. "Galileo and the Causes." In New perspectives on Galileo, edited by Robert E. Butts and Joseph C. Pitt, 161-180. Dordrecht; Boston: D. Reidel, 1978.

Machamer, Peter K. "The Person-Centered Rhetoric of Seventeenth-Century Science." In Persuading Science: The Art of Scientific Rhetoric, edited by Marcello Pera and William R Shea. Canton, MA: Science History Publications, USA, 1991.

January 14,2016 | 18 of 20 zvi.biener@uc.edu 
Machamer, Peter and Spyros Sakellariadis. "The Unity of Hobbes's Philosophy." In Hobbes: War Among Nations, edited by T. Airaksinen and M. A. Bertman, 15-34. London: Gowen, 1989.

Malcolm, Noel. "Hobbes's Science of Politics and his Theory of Politics." In Aspects of Hobbes, 146-156. Essay originally published in Hobbes oggi (1990), A Napoli. (ed.), Milan: Franco Angeli Libri. Oxford, New York: Oxford University Press, 2002.

Mancuso, Paolo. Philosophy of Mathematics and Mathematical Practice in the Seventeenth Century. Oxford: Oxford University Press, 1997.

McKirahan, Richard D. "Aristotle's Subordinate Sciences." British fournal for the History of Science 11 (1978): 197-220.

---. Principles and Proofs: Aristotle's Theory of Demonstrative Science. Princeton, N.J.: Princeton University Press, 1992.

Peterman, Alison. "Spinoza on Extension." Philosopher's Imprint 15 (2015): 1-23.

Pettit, Philip. Made with Words: Hobbes on Language, Mind, and Politics. Princeton: Princeton University Press, 2008.

Philoponus, John. On Aristotle's Physics 2. Trans. A.R. Lacey. Ithaca, N.Y.: Cornell University Press, 1993.

Popkin, Richard H. The third force in seventeenth-century thought. E.J. Brill, 1992.

Randall, John Herman Jr. "The Development of Scientific Method in the School of Padua The Development of Scientific Method in the School of Padua." fournal of the History of Ideas 1 (Apr. 1940): 177-206.

Ryan, Alan. The Philosophy of the Social Sciences. 1st American. $22 \mathrm{~cm}$. New York,: Pantheon Books, 1970.

Sacksteder, William. "Hobbes: Geometrical Objects." Philosophy of Science 48 (1981): 573590.

---. "Hobbes: The Art of the Geometricians." Journal of the History of Philosophy 18 (1980): 131-146.

Schliesser, Eric. "Spinoza and the Philosophy of Science: Mathematics, Motion and Being." In The Oxford Handbook of Spinoza, edited by Michael Della Rocca, 1-26. Oxford University Pres, 2014.

Schönbeck, Jürgen G. "Euclidean and Archimedean traditions in the Middle Ages and the Renaissance." In Companion Encyclopedia of the History and Philosophy of the Mathematical Sciences, edited by Ivor Grattan-Guinness, 173-184. London: Routledge, 1994.

Schuhmann, Karl. "Le Short Tract, premiere oeuvre philosophique de Hobbes." Hobbes Studies 8 (1995): 3-36.

Simplicius. On Aristotle's Physics 2. Edited and translated by Barrie Fleet. Ithaca, N.Y.: Cornell University Press, 1997.

Sorell, Tom. "Descartes, Hobbes and the Body of Natural Science." Monist 71 (1988): 515525.

---. "The Sciences in Hobbes's Politics." In Perspectives on Thomas Hobbes, edited by G. A. J. Rogers and Alan Ryan, 67-80. Oxford New York: Clarendon Press; Oxford University Press, 1988.

January 14, 2016 | 19 of 20 zvi.biener@uc.edu 
South, James B. "Zabarella, Prime Matter, and the Theory of Regressus." Graduate Faculty Philosophy fournal 26 (2005): 79-98.

Talaska, Richard A. "Analytic and Synthetic Method according to Hobbes." fournal of the History of Philosophy 26 (1988): 207-237.

Tuck, Richard. "Optics and sceptics: the philosophical foundations of Hobbes's political thought." In Conscience and casuistry in early modern Europe, edited by Edmund Leites. Cambridge: Cambridge University Press, 1988.

Watkins, John W. N. Hobbes's system of ideas: a study in the political significance of philosophical theories. London: Hutchinson, 1965.

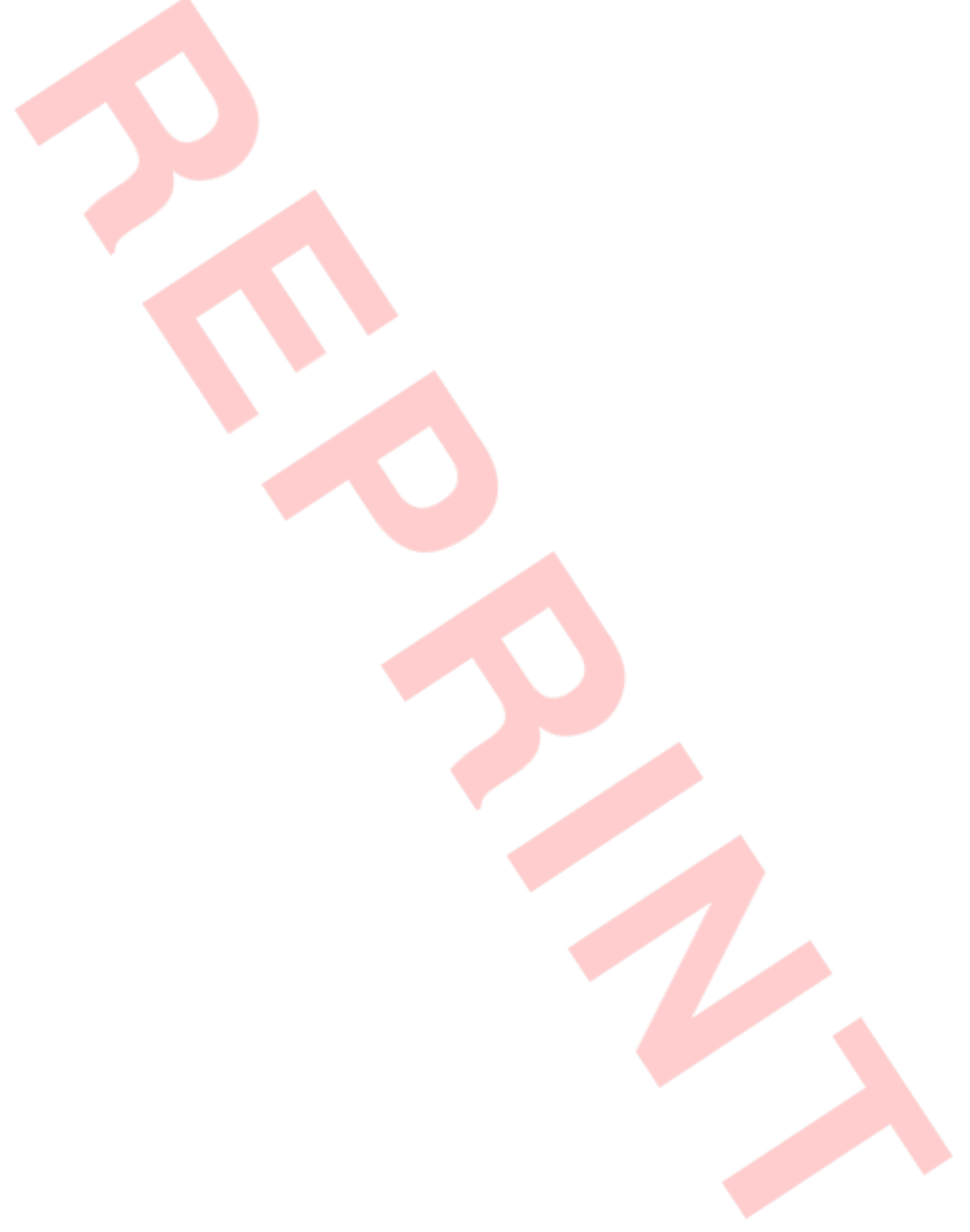

